\title{
Effect of Water Stress on the Yield of Selected Vegetable Crops in the Southern Guinea Savannah Ecological Zone of Nigeria
}

\author{
John Jiya Musa ${ }^{1 *}$, Johnson Kayode Adewumi², Ebierin Akpoebidimiyen Otuaro ${ }^{3}$, \\ Mohammed Tanimu Musa ${ }^{4}$
}

\author{
${ }^{1}$ Department of Agricultural and Bioresources Engineering, Federal University of Technology, Minna, Nigeria \\ ${ }^{2}$ Department of Agricultural and Bioresources Engineering, Federal University of Agriculture, Abeokuta, Nigeria \\ ${ }^{3}$ Civil Engineering Department, Maritime University, Okerenkoko, Nigeria \\ ${ }^{4}$ Department of Agriculture and Environmental Engineering, Kaduna Polytechnic, Kaduna, Nigeria \\ Email: *johnmusa@futminna.edu.ng
}

How to cite this paper: Musa, J.J., Adewumi, J.K., Otuaro, E.A. and Musa, M.T. (2019) Effect of Water Stress on the Yield of Selected Vegetable Crops in the Southern Guinea Savannah Ecological Zone of Nigeria. Open Access Library Journal, 6: e5938.

https://doi.org/10.4236/oalib.1105938

Received: November 19, 2019

Accepted: December 10, 2019

Published: December 13, 2019

Copyright $\odot 2019$ by author(s) and Open Access Library Inc.

This work is licensed under the Creative Commons Attribution International License (CC BY 4.0).

http://creativecommons.org/licenses/by/4.0/

(c) (i) Open Access

\begin{abstract}
Water stress effect on the yield of tomato (Lycopersicum Esculentum) and onion (AlliumCepa) crops was carried. This study is aimed at understanding the required amount of water needed by onion and tomato plants daily and to predetermine the yield expected from scheduled irrigation under limited water supply. Randomised complete block design experimental layout was employed and replicated five times. The irrigation interval observed was controlled on the first block of regular four days; the second, third and fourth blocks were irrigated six, seven, and nine days respectively. The result of onion showed the highest yield of $31.5 \mathrm{~kg} / \mathrm{plot}(12 \mathrm{t} / \mathrm{ha})$ from the four days regular irrigation interval, followed by six days irrigation interval with a yield of $30.9 \mathrm{~kg} /$ plot $(11.77 \mathrm{t} / \mathrm{ha})$. The lowest yield of $18.3 \mathrm{~kg} / \mathrm{plot}(6.97 \mathrm{t} / \mathrm{ha})$ was obtained for the nine days irrigation interval. Similarly, the highest yield of $43.1 \mathrm{~kg} / \mathrm{plot}(16 \mathrm{t} / \mathrm{ha})$ in regular four days irrigation interval and the lowest yield of $13.4 \mathrm{~kg} / \mathrm{plot}(5.1 \mathrm{t} / \mathrm{plot})$ for nine days interval was recorded for tomato. The result of this study shows that irrigating at an interval of four to five days has the highest significant yield of $16 \mathrm{t} / \mathrm{ha}$ and under critical conditions, the farmer can irrigate seven days as up to $65 \%-70 \%$ yield was obtained. Irrigation should not be scheduled nine (9) days because about $42 \%$ of the yield is lost. It is therefore concluded that the yield water use relationship shows that both onion and tomato crops increases with an increase in the rate of seasonal evapotranspiration provided water application rate does not exceed the required amount at the required amount.
\end{abstract}




\section{Subject Areas}

Hydrology

\section{Keywords}

Application Rate, Crop, Irrigation, Water, Yield

\section{Introduction}

Irrigation is a process by which water is applied artificially or applied to the soil for crop use to increase crop production [1] [2] [3]. Irrigation water is applied to supplement the water available from rainfall, soil moisture and the capillary rise of groundwater [4]. In many areas of the world, the amount of precipitation is not adequate to meet the moisture requirements of crops. Hence, successful crop production often requires sufficient provision for irrigation. According to Sharma and Sharma [5], the role of irrigation systems is classified as direct and indirect benefits. The immediate benefits include; increase in crop production output through high yield to attain self-sufficiency in food, cultivation of cash crops, land value appreciates differently, domestic water supply to town and villages and hydro-power generation. The indirect benefits include an increase in the gross domestic product of the country, increase in revenue from the sales of farm produce, tax on food grains, increase in employment, retards migration to cities for livelihood, farm labourers get higher wages, the creation of more jobs/incomes and rise to the whole array of agro-based industries. Irrigation aims to supply water to cropped fields to maintain crop evapotranspiration (ETc) when precipitation is insufficient [6]. Water is becoming increasingly scarce worldwide. Thus aridity and drought are natural causes of scarcity. More recently, human-made desertification and water shortages have aggravated inherent deficiency while at the same time, population is increasing and therein an increase in competition for water among water user sectors and regions [7]. The rapid population growth worldwide and the high demand for water are of great concern. There are growing competitions among municipal, industrial and agricultural use for the limited amount of available good quality water [8]. According to Michael [9], it is essential to accurately estimate irrigation water requirements for water project planning and management. In arid and semi-arid regions precipitation is low and therefore water is scarce. There is, therefore, the need to conserve available water resources.

Improved management and planning of the water resources are needed to ensure proper use and distribution of the water among competing users. To achieve maximum use of water, there is a need for planning as regards water usage which will include the employment of techniques and practices that deliver a more accurate supply of water to crops.

Deficit (or regulated) irrigation is a way of optimising water use efficiency 
(WUE) for higher yields per unit of irrigation water asked. Reduction of return as a result of low irrigation, especially under the situation of scarcity of water, may be compensated by increased production from the additional irrigated area with the water saved from deficit irrigation [10] [11].

Water required by plants from the day of sowing to the day of harvest including the various form of water losses under specific climate regime is called crop water requirement. During this process, adequate soil moisture is maintained through rainfall and irrigation so that it does not limit plant growth and crop yield. This study aims to determine the minimum water requirement for the maximum yield for tomato and onion using a deficit irrigation system.

\section{Material and Method}

\subsection{Study Location}

The research was carried out at Kaduna Polytechnic Demonstration farm, Nariya which is located on latitude $10^{\circ} 16^{\prime} \mathrm{N}$ and longitude $7^{\circ} 21^{\prime} \mathrm{E}$ at an altitude of $600-800 \mathrm{~m}$ above the sea level, during the dry season between the period of November 2016 and April 2017. Figure 1 presents the map of the study area from the map of Kaduna State, Nigeria.

\subsection{Climatic Condition of the Site}

The region according to the NiMet report of 2018, experiences a severe deficit in rainfall from November to April and sometimes a surplus of rain from July to September with an average range of $1500 \mathrm{~mm}$. The average incoming solar radiation range from $15.6 \mathrm{mj} / \mathrm{m}^{2} /$ day in August to $21.0 \mathrm{mj} / \mathrm{m}^{2} /$ day in March. The range in solar radiation implies that light, humid temperature with a significantly limiting potential crop production between November and mid-February with

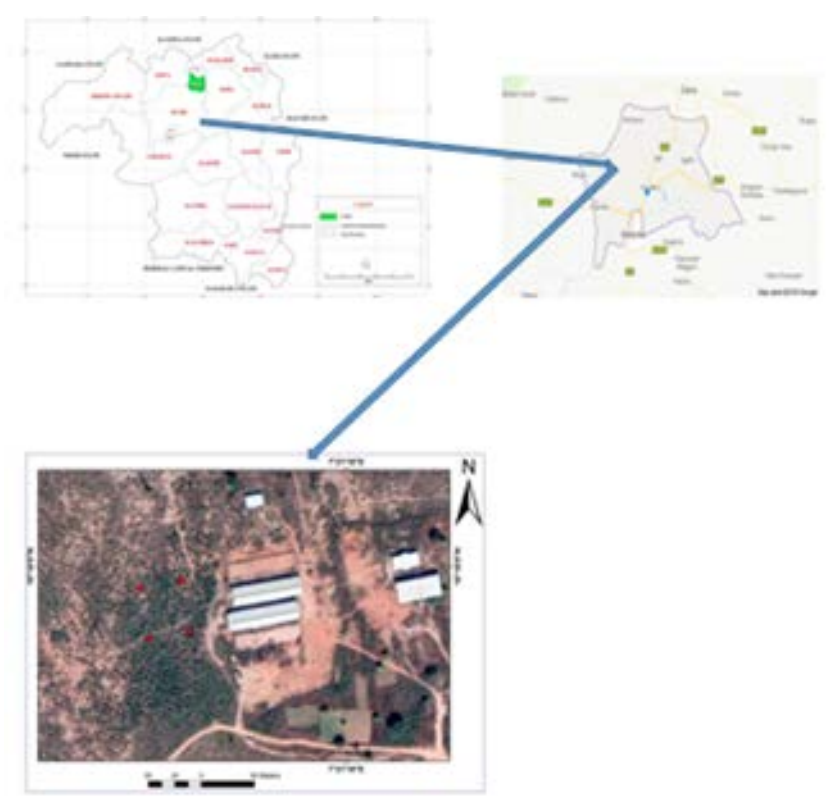

Figure 1. Google map of the study area. 
temperature ranging from $19^{\circ} \mathrm{C}$ to $25^{\circ} \mathrm{C}$, while for the remaining month of the year, the daily temperature ranges from $25^{\circ} \mathrm{C}$ to $32^{\circ} \mathrm{C}$.

\subsection{Soil Texture Classification}

Eight sets of soil samples were collected within the rooting depths of the plots (that is from $0-30 \mathrm{~cm}$ ), and the containers were labelled for ease of identification. The samples were dried at room temperature of $27^{\circ} \mathrm{C}$ for 24 hours. The samples were crushed to fine particles and sieved using a sieve size of $2 \mathrm{~mm} .50 \mathrm{~g}$ of the sieved soil was weighed and placed in a conical flask, and $100 \mathrm{ml}$ of Calgon solution was added to the soil in the flask, mixed and allowed to settle for 30 minutes. A blank solution prepared was poured in a $100 \mathrm{ml}$ Calgon solution into a $1000 \mathrm{ml}$ measuring cylinder, then distil water of $900 \mathrm{ml}$ to reach $1000 \mathrm{ml}$ mark of the measuring cylinder was added to it after which the soil and Calgon were mixed for 30 minutes. The hydrometer was inserted, and the stop clock set after 40 seconds the first reading, as well as the thermometer reading for the temperature, was taken. The second reading was taken after leaving the sample for 2 hours. The texture of the soil samples was determined using a soil texture triangle which was based on relative proportion and specifically on \% sand, silt and clay in a given soil sample. The percentage of sand, silt and clay in the samples was determined from Equations (1)-(4) below;

$$
\begin{gathered}
\%(s i+c)=\frac{C H R 1}{W S} \times 100 \\
\% c=\frac{C H R 2}{W s} \times 100 \\
\% s i=\%(s i+c)-\% c \\
\% s=100-\%(s i+c)
\end{gathered}
$$

where $s i$ is the silt content, $c$ is the clay content, $s$ is the sand content, $C H R 1$ is the first corrected hydrometer reading and $H R 2$ is the second corrected hydrometer reading, while $W s$ is the weight of the sample.

The soil organic matter was determined using Walkley-Black Wet Oxidation meter. The percentage of organic matter in the sample was determined from Equation (5) ( $\mathrm{a}$ and $\mathrm{b}$ ) below;

$$
\begin{aligned}
\text { \%Organic Carbon } & =\frac{N(V 1-V 2) \times 0.3 F}{W} \\
\% \text { organic matter in soil } & =\% \text { Organic carbon } \times 1.724
\end{aligned}
$$

where $N$ is the normality of ferrous sulphate solution; $V 1$ is the $\mathrm{ml}$ ferrous ammonium sulphate required for the blank; $V 2$ is the ferrous ammonium sulphate required for the sample; $W$ is the mass of the sample in gram and $\mathrm{F}$ is the correction factor of 1.33

\subsection{Experimental Design}

Randomised Complete Block Design (RCBD) was used for this experiment. The 
experimental material is assumed to be homogenous, therefore, and there is no restriction in the randomisation. Check basin Surface irrigation method was employed. Each basin was irrigated through a break in the embankment and water allowed through a furrow running along the slope adjacent to the basin until it is ponded to a level of about $15.0 \mathrm{~mm}$ which is the appropriate water requirement for tomato.

The experimental plots were laid out using a chain surveying method. The instruments used were measuring tape, ranging poles and pegs for labelling. The layout was $2 \mathrm{~m} \times 2 \mathrm{~m}$ for each plot, and 20 plots of the experimental unit were used, the total area of $11 \mathrm{~m} \times 12 \mathrm{~m}$ which is $132 \mathrm{~m}^{2}$ or 0.0132 ha for tomato, while the layout for onion was $3 \mathrm{~m} \times 2.5 \mathrm{~m}$ for each plot and 18 plots of the perimental unit was used with the total area of $10.5 \mathrm{~m}^{2}$ or $0.0163 \mathrm{ha}$. This laying out of the plots is in accordance with the works of Maisiri et al., [12]; Medeiros et al., [13]; Anzalone et al., [14]; Ashrafuzzaman et al., [15] and Alliaume et al., [16].

The data collected were subjected to statistical analysis and the means were tested using the least significant difference at $5 \%$ level of significance. All the statistical analyses were conducted using statistical package SPSS 16.

\section{Results and Discussion}

Crop yield and water stress are vital most especially in areas where irrigation is practised. This study will enable the farmer to know the appropriate irrigation water application and scheduling. In this study, the relationship between water stress and crop yield of tomato and onion were established based on the experimental results.

The physical and chemical properties for the experimental plots were determined between depths of $0-15,15-30,30-45$ and $45-60 \mathrm{~cm}$. The topmost layer of the soil gives silt loamy at a depth of $15 \mathrm{~cm}$ while from the depth of 15 to $45 \mathrm{~cm}$ give clay loamy. At $60 \mathrm{~cm}$ depth, the soil texture was clay nature, these classes were determined with the soil texture triangle. This soil texture is the characteristic nature of the soils within the study area and is in accordance with the works of Tuller and Or [17]; Li and Shao [18] and Lu et al., [19]. The chemical properties of the soils show that $\mathrm{pH}$ was slightly alkaline in water and in calcium chloride solution it was strongly alkaline. This is similar to the findings of Mckinley et al., [20]; Sunil et al., [21] and Minasny et al., [22]. The content of sodium $\left(\mathrm{Na}^{+}\right)$, potassium ion $\left(\mathrm{K}^{+}\right)$, magnesium ion $\left(\mathrm{Mg}^{2+}\right)$, calcium ion $\left(\mathrm{Ca}^{2+}\right)$ and CEC was observed to be within the permissible limits of planting onion and tomato plants. The result justified that the soil at the experimental site is suitable for the growth of tomato and onion in northern Nigeria. Table 1 and Table 2 present the physical and chemical properties of the sampled soils obtained from the experimental sites.

\section{Irrigation Scheduling}

The irrigation water requirement for the study location was determined as 8.46 
Table 1. Physical properties of soil in the experimental plot.

\begin{tabular}{cccc}
\hline Depth $(\mathrm{cm})$ & Moisture Content $(\%)$ & Bulk Density $\left(\mathrm{g} / \mathrm{cm}^{3}\right)$ & Textural Class \\
\hline $0-15$ & 20.7 & 1.29 & Silt Loam \\
$15-30$ & 21.9 & 1.29 & Clay Loam \\
$30-45$ & 22.5 & 1.46 & Clay loam \\
$45-60$ & 25.2 & 1.31 & Clay \\
\hline
\end{tabular}

Table 2. Chemical properties of soil in the experimental plot.

\begin{tabular}{cc}
\hline Parameters & Units \\
\hline $\mathrm{pH}$ in water & 5.2 \\
$\mathrm{pH}$ in $0.01 \mathrm{~m} / \mathrm{CaCl}_{2}$ & 4.8 \\
$\%$ organic carbon & 0.92 \\
Available phosphorus $(\mathrm{mg} / \mathrm{kg})$ & 26.8 \\
$\%$ Total nitrogen $(\mathrm{NT})$ & 0.0 \\
$\mathrm{Na}^{+}(\mathrm{mg} / \mathrm{kg})$ & 0.89 \\
$\mathrm{~K}^{+}(\mathrm{mg} / \mathrm{kg})$ & 0.38 \\
$\mathrm{Mg}^{2+}(\mathrm{mg} / \mathrm{kg})$ & 1.40 \\
$\mathrm{Ca}^{2+}(\mathrm{mg} / \mathrm{kg})$ & 4.83 \\
$\mathrm{CEC}^{(\mathrm{mg} / \mathrm{kg})}$ & 8.20 \\
\hline
\end{tabular}

$\mathrm{cm}$ while the daily water requirement was $0.07128 \mathrm{hamm} /$ day, net water requirement was calculated as $0.00825 \mathrm{~m}^{3} / \mathrm{sec}$ and irrigation interval for the site was calculated as 4 days. These parameters gave the actual irrigation interval and crop water need for the plants under consideration.

The growth of onion plant on the experimental site shows an increase in the growth rate in treatment 1 while treatments 2 and 3 had a slight difference between them. This is similar to the works of Pejic et al., [23] and Metwaylhy [24] which indicates that irrigation on treatment 1 is better than the other two regarding growth rate. Thus, treatment 1 stands a better chance to produce better onion bulbs and leaves the analysis of variance for seasonal ET as obtained in the F calculated value as 11.28 for all the treatment and 12.60 for the blocking effect. The values were observed to be higher than the calculated value at $5 \%(2.57)$ and $1 \%$ (4.03) level of significant difference in crop yield. This difference shows that the higher the seasonal evaporation, the higher the crop water requirement for the plants. Similar conditions were observed for the growth rate of tomato. This observed condition is similar to the works of Ismail and Ozawa [25] and Enciso et al. [26] (Figure 2).

The growth stages of onion with ET $243 \mathrm{~mm}$ in $R_{1}$ treatment 1 had the best growth of $85.4 \mathrm{~mm}$ when compared with other treatments as observed in Figure 3. This is closely followed by $R_{3}$ treatment 2 with the growth of $80 \mathrm{~mm}$ at the ET of $232.3 \mathrm{~mm}$, while the least growth was recorded as $71.2 \mathrm{~mm}$ in $R_{4}$ treatment 


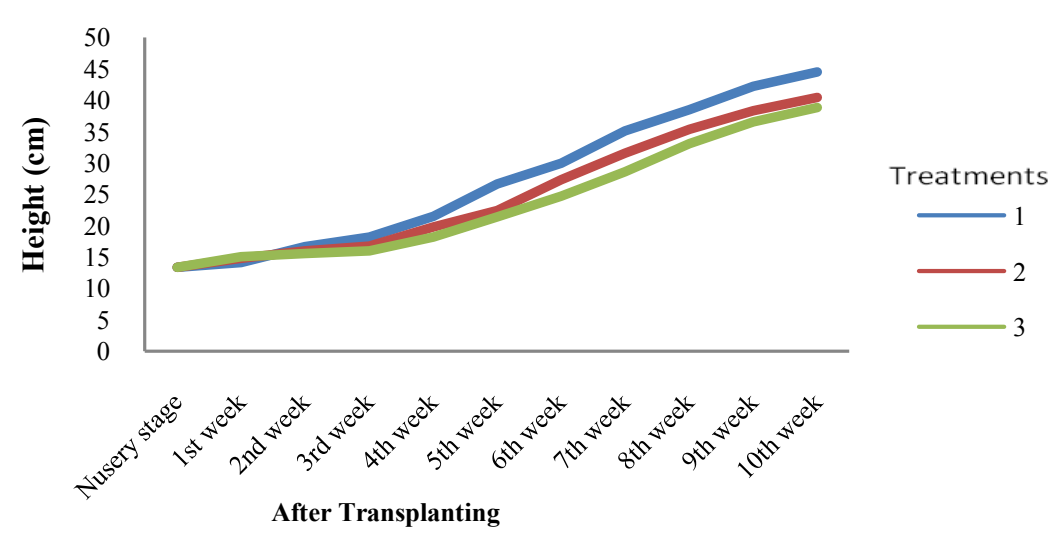

Figure 2. Growth of onion plant concerning irrigation.

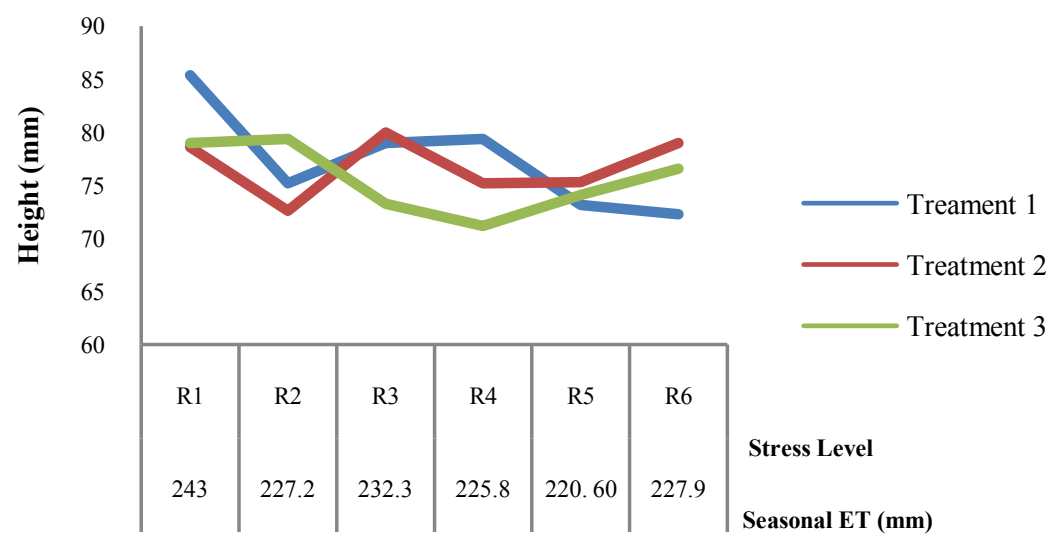

Figure 3. Growth stage and seasonal evapotranspiration (ET) as measured from the experimental plot $(\mathrm{mm})$ for onion.

three which shows that deficit irrigation has a significant effect on the growth of plants.

The highest total yield of onion was recorded at $R_{3}$ at $13.4 \mathrm{~kg}$ followed by $R_{1}$ at $12.7 \mathrm{~kg}$, and the least is $R_{5}$ at $11.5 \mathrm{~kg}$ as observed in Figure 4 . The individuals yield base on treatments have the best yield $R_{3}$ treatment 1 with $5.6 \mathrm{~kg}$ closely followed by $R_{6}$ treatment one which is the control with $5.5 \mathrm{~kg}$, and the least yield was recorded at $R_{5}$ treatment 3 with the value $2.8 \mathrm{~kg}$. This is similar to the works of Shalini [27].

Considering the whole yield based on the seasonal evapotranspiration ET, treatment 1 gave the best yield of $31.5 \mathrm{~kg}$ followed by $25.0 \mathrm{~kg}$ in treatment 2 and $18.3 \mathrm{~kg}$ in treatment 3 with the ET of $464.5 \mathrm{~mm}, 458.7 \mathrm{~mm}$ and $453.6 \mathrm{~mm}$ respectively. This determined value shows that drought stress and scarce water resources are the most significant limiting factors affecting agricultural production. Therefore a need to rank the treatment using LSD of 1.65 value for $T_{1}, T_{2}$, and $T_{3}$. Treatment $T_{1}$ was found to be significant than treatment $T_{2}$ and is highly substantial than Treatment $T_{3}$. This result has shown that under critical condition, irrigation can be carried out at an interval of 10 days since the difference is $5.5 \mathrm{~kg}$. The obtained yield result is in accordance with the works of Serhat and 


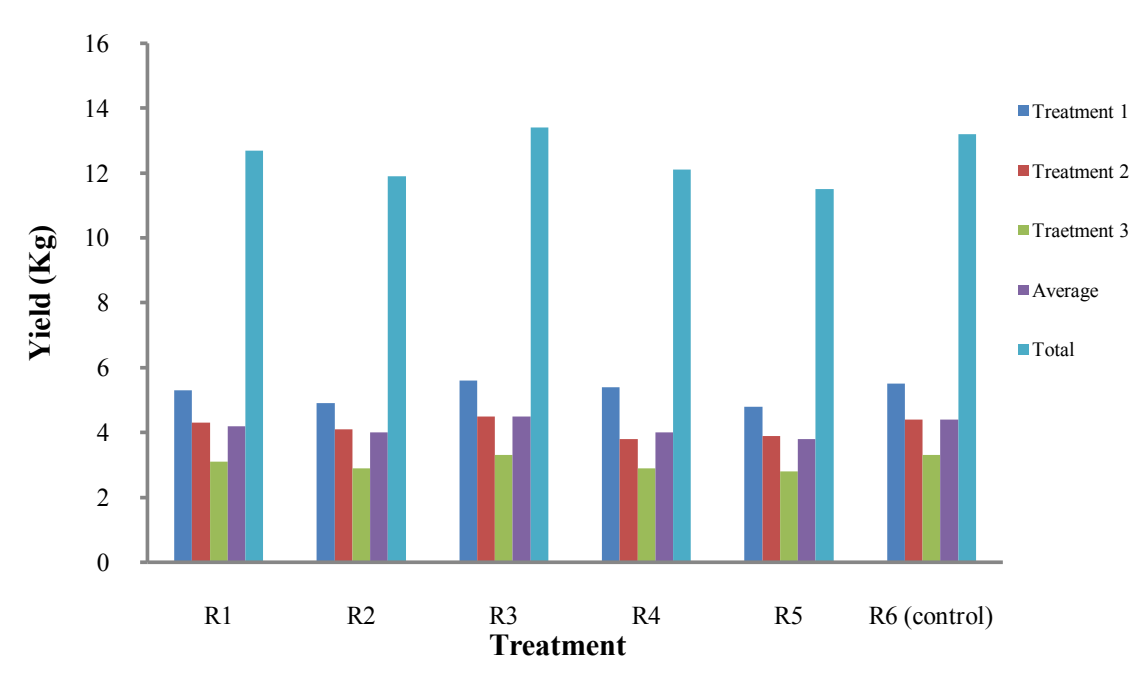

Figure 4. Onion yield (Kg) obtained from the experimental plot.

Cigdem [28]. In their study, they recorded that deficit irrigation effect on onion yielded $51 \mathrm{t} / \mathrm{ha}, 39 \mathrm{t} / \mathrm{ha}$ and $31 \mathrm{t} / \mathrm{ha}$ for treatments $T_{1}, T_{2}$ and $T_{3}$ respectively with ET of $372 \mathrm{~mm}, 292 \mathrm{~mm}$ and $224 \mathrm{~mm}$ respectively (Figure 5).

The growth stages of tomato from the experimental plot have $87.20 \mathrm{~mm}$ as the highest ET value for $Y_{0}$ of $R_{1}$ which is the control. This value is closely followed by $Y_{3}$ of $R_{1}$ a recorded value of $80.00 \mathrm{~mm}$. Almost all the growth stages fell within the range of the averages of between $81.56-66.42 \mathrm{~mm}$ except for values from $Y_{3}$ for $R_{3}, R_{4}$ and $R_{5}$ that are below the range of the averages (Table 3 ). Table 3 further shows that the tomato plants for $Y_{0}$ had the best growth. This growth experienced may be due to the adequate supply of water to the treatment which served as the control plot. The ANOVA statistical analysis shows that F calculated the value of 15.56 for the treatments and 6.93 for the replication were observed to be more than the table values at 5\% (3.49 and 3.26) and at 1\% (5.96 and 5.41) respectively. The level of significance was different for the crop yield which shows that the higher the seasonal evapotranspiration, the more the crop required water.

It was observed that the best yield was at $Y_{0}$ which could be linked to the adequate water supply to the plot which as the control. This yield from $Y_{0}$ was closely followed by yields from $Y_{1}, Y_{2}$ and $Y_{3}$ respectively. This low yield fell below the total average of yields which is recorded at $5.44 \mathrm{~kg} / \mathrm{plot}$ as presented in Table 4. Considering the yield in $\mathrm{t} / \mathrm{ha}$ the results recorded are as follows $Y_{0}(4.32$ $\left.\times 10^{-6}\right), Y_{1}\left(2.66 \times 10^{-6}\right), Y_{2}\left(1.35 \times 10^{-6}\right)$ and $Y_{3}\left(3.72 \times 10^{-7}\right)$. From the results of the yield, it was observed that the control $Y_{0}$ had the best yield in $\mathrm{t} / \mathrm{ha}$ so far while treatment $Y_{3}$ has the lowest yield in $\mathrm{t} / \mathrm{ha}$ as recorded in Table 4 . This is similar to the works of Boamah et al. [29].

ANOVA result shows that the f calculated value of 458.21 for the treatment was higher than the table value at 5\% (3.49) and 1\% (5.96) level of significant differences in crop yield as it is non-substantial. The $\mathrm{F}$ calculated value of 1.58 for the replication was less than table value at 5\% (3.26), and 1\% (5.41) level of 
Table 3. Growth stages and seasonal evapotranspiration as measured from the experimental plot $(\mathrm{mm})$.

\begin{tabular}{cccccccc}
\hline Treatment & $R_{1}(\mathrm{~mm})$ & $R_{2}(\mathrm{~mm})$ & $R_{3}(\mathrm{~mm})$ & $R_{4}(\mathrm{~mm})$ & $R_{5}(\mathrm{~mm})$ & Total $(\mathrm{mm})$ & $\begin{array}{c}\text { Average } \\
\mathrm{mm} / \mathrm{plot}\end{array}$ \\
\hline$Y_{0}$ & 87.2 & 85.4 & 79.6 & 79 & 76.6 & 407.8 & 81.56 \\
$Y_{1}$ & 79.4 & 79.4 & 74.1 & 73.2 & 72.3 & 378.4 & 75.68 \\
$Y_{2}$ & 75.2 & 73.3 & 73.3 & 72.3 & 71.2 & 365.3 & 73.06 \\
$Y_{3}$ & 80 & 72.6 & 62.2 & 60 & 57.3 & 332.1 & 66.42 \\
Total & 321.8 & 310.7 & 289.2 & 284.5 & 277.4 & 1483.6 & 283.72 \\
\hline
\end{tabular}

Table 4. Yield obtained from the experimental plot.

\begin{tabular}{cccccccc}
\hline Treatment & $R_{1}$ & $R_{2}$ & $R_{3}$ & $R_{4}$ & $R_{5}$ & $\begin{array}{c}\text { Total } \\
(\mathrm{Kg})\end{array}$ & $\begin{array}{c}\text { Average } \\
(\mathrm{kg} / \mathrm{plot})\end{array}$ \\
\hline$Y_{0}$ & 10.20 & 10.60 & 11.30 & 11.01 & 10.90 & 54.01 & 10.80 \\
$Y_{1}$ & 6.20 & 6.05 & 6.35 & 7.28 & 7.30 & 33.18 & 6.64 \\
$Y_{2}$ & 3.20 & 2.90 & 3.50 & 3.20 & 4.10 & 16.90 & 3.38 \\
$Y_{3}$ & 1.30 & 1.15 & 0.40 & 0.60 & 1.20 & 4.65 & 0.93 \\
Total & 20.90 & 20.70 & 21.55 & 22.09 & 23.50 & 108.74 & 21.75 \\
\hline
\end{tabular}

- Seasonal Evapotranspiration MM

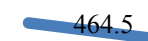

453.6

\begin{tabular}{|c|c|c|}
\hline $31.5 \mathrm{~kg}$ & $25.0 \mathrm{~kg}$ & $18.3 \mathrm{~kg}$ (Yield) \\
1 & 2 & 3 \\
\hline
\end{tabular}

Figure 5. Stress effect on onion yield and seasonal evapotranspiration ET.

significant differences for crop yield. Therefore, there is the need to rank the means treatment using LSD at $5 \%$ and $1 \%$ of 27.98 and 42.04 respectively. $Y_{1}, Y_{2}$ and $Y_{3}$ were found to be highly significant where $Y_{1}, Y_{2}$ and $Y_{3}$ are stress for 3 days, 5 days and 7 days more than 7 days regular interval respectively.

The relationship of yield and water use of tomato established in Figure 6 shows that as the water use increases the yield of tomato also increases. This increase in yield implies that water deficit causes the defect to crops and affects the quality and quantity of the crop to be produced. This is similar to the works of Blum [30] [31] and Hatirli et al. [32].

The yield of tomato from the $Y_{0}$ site has the highest yield of $54.01 \mathrm{~kg}$ on the plot where seven days irrigation interval was applied, as the irrigation interval 
$\longrightarrow$ Yields $(\mathrm{kg}) \quad$ Seasonal ET $(\mathrm{mm})$
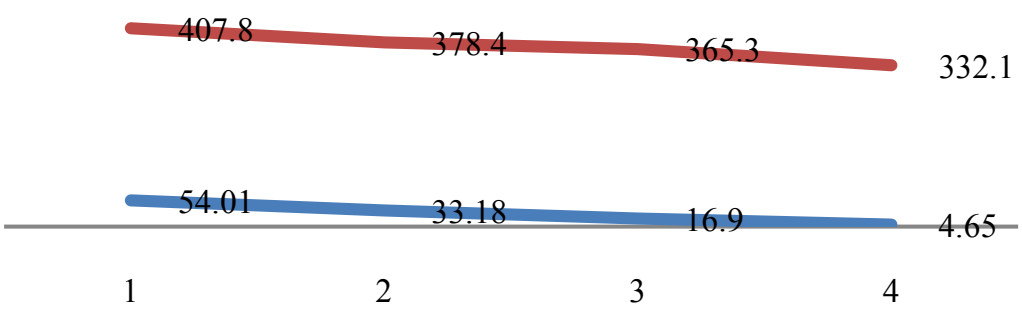

Figure 6. Showing yield - water use relationship.

increases the yield decreases as observed in Figure 6 . This yield is closely followed by $33.18 \mathrm{~kg}$ and $16.9 \mathrm{~kg}$ for $Y_{1}$ and $Y_{2}$ respectively. This is in agreement with the study of Sladana et al. [33] where they obtain $44.05 \mathrm{~g}, 36.08 \mathrm{~g}$ and $36.03 \mathrm{~g}$ for $Y_{1}, Y_{2}$ and $Y_{3}$ at plant water use of $29.56 \mathrm{~mm}, 21.19 \mathrm{~mm}$ and 21.13 respectively.

\section{Conclusions}

In this study, irrigation treatments significantly affected yield, height, diameter and weight of onion bulbs and tomato fruits. There was a significant difference in the yield from the result obtained, at the three growth stages of both onion and tomato when it was stressed with an additional day from the regular interval of 7 days.

The maximum yield was both obtained from treatment 1 (control) which proved that no stress was observed during the growth stage. For onion $T_{2}$ which was stressed for an additional three days (10 days) shows little importance and $T_{3}$ which was noted for an additional seven days (14 days) shows more stress while for tomato $T_{2}$ and $T_{3}$ which were stressed for another three days and 5 days interval shows little importance based on the yield obtained. Finally, the yield water use relationship shows that the yield of onion and tomato crop increases with an increase in the rate of seasonal evapotranspiration.

\section{Conflicts of Interest}

The authors declare no conflicts of interest regarding the publication of this paper.

\section{References}

[1] Sun, H., Liu, C., Zhang, X., Shen, Y. and Zhang, Y. (2006) Effect of Irrigation on Water Balance, Yield and WUE of Winter Wheat in the North China Plain. Agricultural Water Management, 85, 211-218.

https://doi.org/10.1016/j.agwat.2006.04.008

[2] Ahmed, F.E. and Suliman, A.S.H. (2010) Effect of Water Stress Applied at Different Stages of Growth on Seed Yield and Water-Use Efficiency of Cowpea. Agricultural and Biology Journal of North America, 1, 534-540. 
[3] Bitri, M., Grazhdani, S. and Ahmeti, A. (2014) Validation of the AquaCrop Model for Full and Deficit Irrigated Potato Production in Environmental Condition of Korca Zone, South-Eastern Albina. International Journal of Innovative Research in Science, Engineering and Technology, 3, 12013-12020.

[4] Xu, C. and Leskovar, D.I. (2014) Growth, Physiology and Yield Responses of Cabbage to Deficit Irrigation. Horticultural Science, 41, 138-146. https://doi.org/10.17221/208/2013-HORTSCI

[5] Sharma, R.K. and Sharma, T.K. (2006) Irrigation Engineering. S. Chand \& Company Ltd., Mumbai.

[6] Arku, A.Y., Musa, S.M. and Mofoke, A.L.E. (2012) Determination of Water Requirement for Irrigation Hibiscus (Rosasinensis). Journal of Hytotechnology in Environment Sanitation, 1, 37-42.

[7] Rozek, E., Nurzynska-Wierdak, R. and Kosior, M. (2013) Efficiency of Some Agrotechnical Treatments in Quantity and Quality Yield Modification of Leaf Celery (Apium graveolens L. var. secalinum Alef.). Acta Scientiarum Polonorum Hortorum Cultus, 12, 227-239.

[8] Sato, T., Qadir, M., Yamamoto, S., Endo, T. and Zahoor, A. (2013) Global, Regional, and Country Level Need for Data on Wastewater Generation, Treatment, and Use. Agricultural Water Management, 130, 1-13.

[9] Michael, A.M. (1999) Irrigation Theory and Practice. Vikas Publishing House India, New Delhi.

[10] Ayana, M. (2011) Deficit Irrigation Practices as Alternative Means of Improving Water Use Efficiencies in Irrigated Agriculture: Case Study of Maize Crop at Arba Minch, Ethiopia. African Journal of Agricultural Research, 6, 226-235.

[11] Igbadun, H.E. and Oiganji, E. (2012) Crop Coefficients and Yield Response Factors for Onion (Allium Cepa. L) under Deficit Irrigation and Mulch Practices in Samaru, Nigeria. African Journal of Agricultural Research, 7, 5137-5152.

[12] Maisiri, N., Senzanje, A., Rockstrom, J. and Twomlow, S.J. (2005) On Farm Evaluation of the Effect of Low Cost Drip Irrigation on Water and Crop Productivity Compared to Conventional Surface Irrigation System. Physics and Chemistry of the Earth, Parts $A / B / C$, 30, 783-791. https://doi.org/10.1016/j.pce.2005.08.021

[13] Medeiros, M.A., Sujii, E.R. and Morais, H.C. (2009) Effect of Plant Diversification on Abundance of South American Tomato Pinworm and Predators in Two Cropping Systems. Horticultura Brasileira, 27, 300-306. https://doi.org/10.1590/S0102-05362009000300007

[14] Anzalone, A., Cirujeda, A., Aibar, J., Pardo, G. and Zaragoza, C. (2010) Effect of Biodegradable Mulch Materials on Weed Control in Processing Tomatoes. Weed Technology, 24, 369-377. https://doi.org/10.1614/WT-09-020.1

[15] Ashrafuzzaman, M., Halim, M.A., Ismail, M.R., Shahidullah, S.M. and Hossain, M.A. (2011) Effect of Plastic Mulch on Growth and Yield of Chilli (Capsicum annuum L.). Brazilian Archives of Biology and Technology, 54, 321-330. https://doi.org/10.1590/S1516-89132011000200014

[16] Alliaume, F., Rossing, W.A.H., Tittonell, P., Jorge, G. and Dogliotti, S. (2014) Reduced Tillage and Cover Crops Improve Water Capture and Reduce Erosion of Fine Textured Soils in Raised Bed Tomato Systems. Agriculture, Ecosystems \& Environment, 183, 127-137. https://doi.org/10.1016/j.agee.2013.11.001

[17] Tuller, M. and Or, D. (2005) Water Films and Scaling of Soil Characteristic Curves at Low Water Contents. Water Resources Research, 41, W09403.

https://doi.org/10.1029/2005WR004142 
[18] Li, Y.Y. and Shao, M.A. (2006) Change of Soil Physical Properties under Long-Term Natural Vegetation Restoration in the Loess Plateau of China. Journal of Arid Environments, 64, 77-96. https://doi.org/10.1016/j.jaridenv.2005.04.005

[19] Lu, S., Ren, T., Gong, Y. and Horton, R. (2007) An Improved Model for Predicting Soil Thermal Conductivity from Water Content at Room Temperature. Soil Science Society of America Journal, 71, 8-14. https://doi.org/10.2136/sssaj2006.0041

[20] Mckinley, J.D., Thomas, H.R., Williams, K.P. and Reid, J.M. (2001) Chemical Analysis of Contaminated Soil Strengthened by the Addition of Lime. Engineering Geology, 60, 181-192. https://doi.org/10.1016/S0013-7952(00)00100-9

[21] Sunil, B.M., Nayak, S. and Shrihari, S. (2006) Effect of pH on the Geotechnical Properties of Laterite. Engineering Geology, 85, 197-203.

https://doi.org/10.1016/j.enggeo.2005.09.039

[22] Minasny, B., McBratney, A.B., Brough, D.M. and Jacquier, D. (2011) Models Relating Soil pH Measurements in Water and Calcium Chloride that Incorporate Electrolyte Concentration. European Journal of Soil Science, 62, 728-732. https://doi.org/10.1111/j.1365-2389.2011.01386.x

[23] Guozdanovic, P.B., Vargal, J., Melic, S., Cupina, A., Krstic, D. and Cupina, B. (2011) Effect of Irrigation Schedules on Yield and Water Use of Onion (Allium Cepa L.) African Journal of Biotechnology, 10, 2644-2652. https://doi.org/10.5897/AJB10.1059

[24] Metwaylhy, A.K. (2011) Effect of Water Supply on Vegetative Growth and Yield Characteristics. Australian Journal of Basic and Applied Sciences, 5, 3016-3023.

[25] Ismail, M.S. and Ozawa, K. (2009) Effect of Irrigation Interval on Growth Characteristics, Plant Water Stress Tolerance and water Use Efficiency for Chile Pepper. Proceeding of the 13th International Water Technology Conference, Hurghada, Egypt, 11-13 March 2009, 545-556.

[26] Enciso, J., Jifon, J., Weidenfeld, B. and Belsons, S. (2009) Onion Yield and Quality Response to Two Irrigation Scheduling Strategies. Scientia Horticulturae, 120, 301-305. https://doi.org/10.1016/j.scienta.2008.11.004

[27] Shalini, S. (2012) Responses of Onion (Allim cepa L.) to Different Level of Irrigation Water. Agricultural Water Management, 89, 161-166.

[28] Serhat, A. and Cigdem, D. (2009): Deficit Irrigation Effects on Onion (Allium cepa L. E.T. Grano 502) Yield in Unheated Greenhouse Condition. Journal of Food, Agriculture \& Environment, 7, 239-243.

[29] Boamah, P.O., Sam-Amoah, L.K. and Owusu-Sekyere, J.D. (2010) Effect of Irrigation Interval on Growth and Development of Tomato under Sprinkler. Asian Journal of Agricultural Research, 4, 196-203. https://doi.org/10.3923/ajar.2010.196.203

[30] Blum, A. (2005) Drought Resistance, Water-Use Efficiency and Yield PotentialAre They Compatible, Dissonant, or Mutually Exclusive? Australian Journal of Agricultural Research, 56, 1159-1168. https://doi.org/10.1071/AR05069

[31] Blum, A. (2009) Effective Use of Water (EUW) and Not Water-Use Efficiency (WUE) Is the Target of Crop Yield Improvement under Drought Stress. Field Crops Research, 112, 119-123. https://doi.org/10.1016/j.fcr.2009.03.009

[32] Hatirli, S.A., Ozkan, B. and Fert, C. (2006) Energy Inputs and Crop Yield Relationship in Greenhouse Tomato Production. Renewable Energy, 31, 427-438. https://doi.org/10.1016/j.renene.2005.04.007

[33] Slandana, S, Liuf., Radmila, S., Jacobsens, E., Jensenc, R. and Zzorica, J. (2009) Comparative Effects of Partial Root Zone Drying and Deficit Irrigation on Growth and Physiology of Tomato Plants. Archives of Biological Sciences, 61, 801-810. https://doi.org/10.2298/ABS0904801S 